\title{
Influência da desinfecção por energia de micro-ondas em biofilme multi-espécies sobre próteses totais
}

\author{
Altair A Del Bel Cury (PQ); SE Souza (PG); AA Sampaio (PG); Rayane R Araújo (IC) \\ Resumo \\ Usuários de próteses totais frequentemente apresentam infecções fúngicas, sendo o fungo Candida \\ Albicans o principal agente etiológico. Estudos demonstram que a virulência e patogenicidade da Candida \\ albicans é modulada pela presença de bactérias orais. Este estudo objetivou avaliar o efeito da desinfecção \\ por energia de micro-ondas sobre próteses cobertas por biofilmes multiespécie.
}

Palavras Chave: biofilmes, candidose, resina.

\section{Introdução}

A candidose é a infecção oral fúngica mais comum em usuários de próteses totais, sendo o fungo Candida albicans apontado como principal agente etiológico. Em adição, estudos recentes demonstram que a virulência e patogenicidade da Candida albicans é modulada pela presença de bactérias orais. Ao passo que, estudos de métodos de desinfecção de próteses totais devem considerar tal variedade microbiológica dos biofilmes orais. Desta forma, este estudo objetivou avaliar o efeito da desinfecção por energia de micro-ondas sobre materiais de base de prótese cobertos por um biofilme multiespécie composto por Candida albicans, Veillonella dispar, Streptococcus mutans, Streptococcus oralis, Fusubacterium nucleatum e Actinomyces naes/undii (Guggenheim et al; 2001) ${ }^{1}$.

\section{Resultados e Discussão}

Espécimes de PMMA (polimetilmetacrilato) foram confeccionados e padronizados quanto à rugosidade superficial. Os espécimes foram aleatoriamente distribuídos em grupos controle e experimental, com e sem exposição a energia de micro-ondas, respectivamente. Sobre estes foram desenvolvidos biofilmes multiespécies pelo período de 64,5 horas, em seguida estes foram fixados em próteses totais as quais foram imersas em água destilada onde permaneceram por 3 minutos, na ausência de exposição a energia de micro-ondas (grupo controle) ou, submetidos a exposição com potência de $450 \mathrm{~W}$ por 3 minutos (grupo experimental)(Senna et al2012) ${ }^{2}$. Ao realizar a contagem de microrganismos viáveis em meios seletivos, pode-se notar que a desinfecção do PMMA por irradiação de 450W por 3 minutos é eficaz, já que não houve crescimento de microrganismos no grupo experimental (espécimes expostos à irradiação).

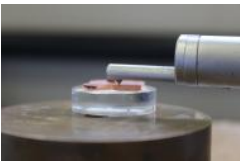

Fig . Análise de rugosidade superficial para padronização das amostras

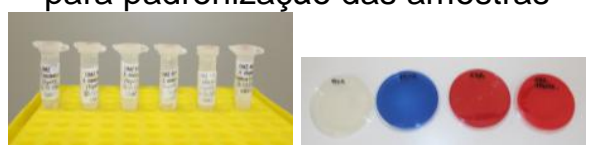

Fig 2 e 3. Cepas bacterianas ( $A$. naeslundii, Veillonella díspar, Fusobacterium nucleatum, Streptococcus mutans, Streptococcus oralis) e fúngica (Candida Albicans) e seus respectivos meios seletivos.

\section{Conclusões}

Conclui-se que a irradiação por energia de microondas pode ser utilizada para a desinfecção de próteses totais, já que mostrou ser eficaz em um biofilme multispécie.

\section{Agradecimentos}

Agradeço às pós graduandas Aline $\mathrm{S}$. e Samilly S. pelo trabalho e amizade e à todos os colegas dos laboratórios em que trabalhei (FOP/Unicamp). De forma especial, agradeço minhas orientadoras de Iniciações Científicas Prof $^{\text {as }}$ Altair Del Bel Cury e Lívia A. Tenuta por me apresentarem o universo científico.

Guggenheim B, Giertsen E, Schupbach P, Shapiro S, 2001 Validation of an in vitro biofilm modelof supragingival plaque. J Dent Res 80(1):363-370.

2 Senna PM, da Silva WJ, Cury AA. Denture disinfection by microwave energy: influence of Candida albicans biofilm. Gerodontology. 2012 Jun;29(2):e186-91 